\title{
Correction to: Influence of Malnutrition on the Pharmacokinetics of Drugs Used in the Treatment of Poverty-Related Diseases: A Systematic Review
}

\author{
Luka Verrest $^{1}$ - Erica A. Wilthagen ${ }^{2}$. Jos H. Beijnen ${ }^{1}$. Alwin D. R. Huitema ${ }^{1,3,4} \cdot$ Thomas P. C. Dorlo $^{1}$
}

Published online: 25 October 2021

(c) The Author(s) 2021

\section{Correction to: \\ Clinical Pharmacokinetics (2021) 60:1149-1169 \\ https://doi.org/10.1007/s40262-021-01031-z}

The article titled "Influence of Malnutrition on the Pharmacokinetics of Drugs Used in the Treatment of Poverty-Related Diseases: A Systematic Review”, written by Luka Verrest, Erica A. Wilthagen, Jos H. Beijnen, Alwin D. R. Huitema, Thomas P. C. Dorlo was originally published Online First without open access. After publication in volume 60, issue 9, pages 1149-1169, the Authors requested that the article be made an open access publication on September 29th.

This article is now licensed under a Creative Commons Attribution-NonCommercial 4.0 International License, which permits any non-commercial use, sharing, adaptation, distribution and reproduction in any medium or format, as long as you give appropriate credit to the original author(s) and the source, provide a link to the Creative Commons licence, and indicate if changes were made. The images or other third party material in this article are included in the article's Creative Commons licence, unless indicated otherwise in a credit line to the material. If material is not included in the article's Creative Commons licence and your intended use is not permitted by statutory regulation or exceeds the permitted use, you will need to obtain permission directly from the copyright holder. To view a copy of this licence, visit http://creativecommons.org/licenses/ by-nc/4.0/.

The original article has been corrected.

Open Access This article is licensed under a Creative Commons Attribution-NonCommercial 4.0 International License, which permits any non-commercial use, sharing, adaptation, distribution and reproduction in any medium or format, as long as you give appropriate credit to the original author(s) and the source, provide a link to the Creative Commons licence, and indicate if changes were made. The images or other third party material in this article are included in the article's Creative Commons licence, unless indicated otherwise in a credit line to the material. If material is not included in the article's Creative Commons licence and your intended use is not permitted by statutory regulation or exceeds the permitted use, you will need to obtain permission directly from the copyright holder. To view a copy of this licence, visit http://creativecommons.org/licenses/by-nc/4.0/.
The original article can be found online at https://doi.org/10.1007/ s40262-021-01031-z.

Thomas P. C. Dorlo

t.dorlo@nki.nl

1 Department of Pharmacy and Pharmacology, Antoni van Leeuwenhoek Hospital/The Netherlands Cancer Institute, PO Box 90440, 1006 BK Amsterdam, The Netherlands

2 Scientific Information Service, Antoni van Leeuwenhoek Hospital/The Netherlands Cancer Institute, Amsterdam, The Netherlands

3 Department of Clinical Pharmacy, University Medical Center Utrecht, Utrecht University, Utrecht, The Netherlands

4 Department of Pharmacology, Princess Máxima Center for Pediatric Oncology, Utrecht, The Netherlands 